\title{
Comunidades provisórias entre pessoas quaisquer: encontros de delicadeza, criação artística e diferença
}

\author{
Juliana Araújo Silva ${ }^{a}$, Elizabeth Maria Freire de Araújo Lima ${ }^{b}$ \\ ${ }^{a}$ Centro de Atenção Psicossocial, CAPS Infantil Brasilândia, São Paulo, SP, Brasil.

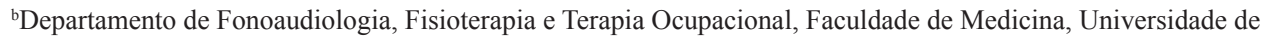 \\ São Paulo - USP, São Paulo, SP, Brasil.
}

\begin{abstract}
Resumo: Este artigo foi elaborado a partir da pesquisa intitulada "Poéticas e marginalidade: experiência no Projeto Cidadãos Cantantes". Ele aborda parte da experiência coletiva vivida no Projeto Cidadãos Cantantes, focalizando os modos pelos quais se produz grupalidade, formas de estar junto ou de estabelecer convivência, e apresenta uma análise sobre tais procedimentos. O Projeto Cidadãos Cantantes é, atualmente, composto pela Oficina de Coral Cênico e pela Oficina de Dança e Expressão Corporal, e surgiu a partir do movimento da luta antimanicomial, em 1992. Através da participação no projeto e de uma parceria de oito, as autoras elaboraram narrativas que conduzem a análise da experiência em questão. Compreende-se que, ao buscar promover encontros entre pessoas quaisquer e não a partir de uma definição ou diagnóstica, o Projeto pode agregar pessoas de forma desejante e cooperativa. Desta forma, os modos de relações vigentes nas oficinas do Projeto fortalecem a produção de encontros pautados na potência, na criação e no respeito às diferenças.
\end{abstract}

Palavras-chave: Artes, Saúde Mental, Terapia Ocupacional.

\section{Interim communities between singularities: encounters of delicacy, artistic creation and difference}

\begin{abstract}
This article is an outcome of the dissertation "Poetics and marginality: the Project Cidadãos Cantantes experience" that focused on the chorus collective experience, in the project focusing the formation of groupality, the ways of being together or coexisting, and presents an analysis of these procedures. This Project was created on 1992 in the interface of antimanicomial movement. It consists in two workshops: a scenic chorus workshop and a workshop of dance and body expression. Through the project, the authors elaborated a narrative that leads the analyses of the mentioned experience. It is understood that promoting encounters between any kind of people, with or without psychic suffering - and not grouped based on a definition or diagnosis, the project can bring people in a desiring and cooperatively manner-. Therefore, the relationships developed during the project's workshops strengthen the production of guided encounters in power, in the creation and respect for differences.
\end{abstract}

Keywords: Art, Mental Health, Occupational Therapy.

\footnotetext{
Autor para correspondência: Juliana Araújo Silva, Centro de Docência e Pesquisa em Terapia Ocupacional, Faculdade de Medicina, Universidade de São Paulo, Rua Cipotânea, 51, Cidade Universitária, CEP 05508-900, São Paulo, SP, Brasil, e-mail: juliana.arsi@gmail.com

Recebido em Fev. 25, 2015; $1^{\text {a }}$ Revisão em Maio 04, 2015; Aceito em Jun. 23, 2015.
} 


\section{Introdução}

E cada ser é e tem de ser o seu modo de ser, a sua maneira de jorrar: ser tal qual é (AGAMBEN, 1993, p. 79).

Não se trata mais das utilizaçôes ou das capturas, mas das sociabilidades e comunidades. Como individuos se compóem para formar um individuo superior, ao infinito? Como um ser pode se apoderar de outro no seu mundo, conservando-lhe ou respeitando-lhe, porém, as relaçôes e o mundo próprios? (DELEUZE, 2002, p. 131).

Este texto é parte da pesquisa "Poéticas e marginalidade: experiência no Projeto Cidadáos Cantantes". Através da parceria entre este projeto e o Laboratório Arte, Corpo e Terapia Ocupacional da Universidade de Sáo Paulo, realizamos uma cartografia da experiência nas oficinas que o compóem - a Oficina de Coral Cênico e a Oficina de Dança e Expressão Corporal-, construindo narrativas que, entrelaçadas com ideias e conceitos, constroem a análise apresentada.

O Projeto Cidadáos Cantantes visa a fomentar a criação artística coletiva, o respeito às diferenças e os diferentes modos de expressão e vida. Ele surgiu em 1992 em meio a luta antimanicomial e atua numa região de fronteira entre os campos das artes e da saúde. Suas oficinas são abertas, gratuitas e acontecem em uma galeria municipal, no centro da cidade de Sáo Paulo.

A "subjetividade qualquer", conceituada por Giorgio Agambem, e alguns verbetes de "Como viver Juntos", de Roland Barthes (2003a), foram ideias-chave para compreender essa comunidade provisória, como denominamos, formada por seres cuja premissa para estarem juntos é o desejo de criação artística coletiva e a potência experimentada em cada um através dos encontros.

Em 2012, quando fazíamos um levantamento das canções que marcaram as trajetórias das pessoas na Oficina de Coral Cênico, para montar o repertório de comemoração dos 20 anos, "O seu olhar", de Arnaldo Antunes e Paulo Tati, foi uma canção citada por quase todos do grupo. Esta canção explicita a relação com o outro, o desejo de sua presença, a experiência de ser composto pelo outro no encontro, pelos olhares. Ela anuncia também o modo de funcionamento das duas Oficinas do Projeto e o desafio que enfrentam a cada dia: constituir-se em oficinas abertas a todos que quiserem experimentar-se nas linguagens trabalhadas, sem crivos de idade, classe social, nível educacional, experiência prévia, diagnósticos em saúde, etc. etc. etc.

A Oficina de Coral Cênico do Projeto Cidadãos Cantantes acontece há 22 anos e a Oficina de Dança e Expressão Corporal, há 13 anos, todas as semanas. Os encontros são, por vezes, bem movimentados, com a presença de muitos participantes; noutras, acontecem em um ritmo lento, com um número menor de participantes.

Este artigo apresenta um relato e uma análise de experiência nessas duas oficinas que compóem o Projeto Cidadãos Cantantes, focalizando seus esforços para organizar paisagens de convivência entre pessoas quaisquer, numa composição heterogênea, que visa a fomentar a criação artística coletiva, o respeito às diferenças e os diferentes modos de expressão e vida.

\section{Discussão}

\subsection{Conviver. Com-viver, um desafio.}

O Projeto Cidadáos Cantantes faz um deslocamento em relação a concepçôes de agrupamentos por semelhança ou identidade. Mesmo tendo seu nascimento ligado às questôes da saúde mental, não teve como foco ser um espaço que abarcasse somente usuários de instituiçóes de saúde mental, mas sim ser um espaço aberto a qualquer um.

Quando acompanhamos a história da loucura, percebemos como é presente a dificuldade do estar junto entre as pessoas - as proximidades e as distâncias desmedidas, desconfigurantes, os diversos tipos de violência e poderes exercidos sobre os outros, com seu ápice no asilamento. Os modos de existência singulares, que encontram certa fragilidade em lidar com as forças dos encontros e do mundo, envoltos em sofrimentos, têm sido, ao longo dos anos, observados, descritos e classificados. Contudo, ao seguir os princípios da luta antimanicomial e $\mathrm{da}$ reforma psiquiátrica quanto às tentativas de provocar o corpo social em relação ao sofrimento, o isolamento, o asilamento e o estar junto na diferença, não faria sentido para o Projeto ser um espaço que partisse de uma identidade, como critério para a participação das pessoas, mas sim o desejo de estar com o outro, de conviver.

Conviver é uma ação que se refere a algo mais para além de estar junto no mesmo espaço, seja esta a casa, a cidade, a fábrica etc. A convivência passa pela construção de maneiras através das quais é possível, ou não, estar junto. Possivelmente, existam várias hipóteses quanto a este desafio, do "com-viver", "coexistir", que o coloque como uma dificuldade ou como uma habilidade humana. Pensamos nele 
como um desafio que acompanha a história da vida em comum.

Ao partirmos da compreensão de que as formas de estar junto não são dadas e sim construídas, percebemos que, cotidianamente, encontramo-nos em situaçóes nas quais é preciso organizar uma convivência - no transporte público, em um ambiente de trabalho, em um ambiente escolar. Os laços de amizade talvez sejam potentes exemplos que nos colocam a pensar a necessidade do outro - ou dos outros - para a vida. Pensamos que a sustentação e a continuidade do Projeto Cidadáos Cantantes estão relacionadas a esta necessidade e à importância de se fazer comunidade. Este fazer pode se dar a partir do olhar e da presença de outros quaisquer, em encontros que revelam a potência de estar junto.

Habitamos um cenário em que circula um saudosismo de uma época em que conviver era aparentemente mais fácil e melhor. Aponta-se, frequentemente, que hoje não há mais comunidades e sim mais conflitos, mais guerras, mais destruiçóes.

Faz-se um uso excessivo da palavra "comunidade" para referir-se a agrupamentos quase estéreis de participação das pessoas, que acontecem por denominadores comuns de semelhanças ou de traços identitários. Por exemplo, constantemente percebemos que os bairros periféricos da cidade, anteriormente referidos como periferias ou favelas, são agora designados pelo termo "comunidade": "a comunidade do jardim São Luís, a comunidade da Brasilândia”... O que faz com que sejam chamados de comunidades? $\mathrm{O}$ fato de as pessoas compartilharem o mesmo território geográfico, a mesma subprefeitura, a mesma miséria? Seria um novo jeito, mais arrumadinho e harmonioso, de se referir à situação de vulnerabilidade social?

A mesma palavra é usada ainda para designar os agrupamentos étnicos ou religiosos: "a comunidade judaica, a comunidade católica etc.", apesar de ainda pontuar uma diferença quanto aos bairros periféricos, por serem agrupamentos que se fazem, aparentemente, mais próximos aos interesses comuns das pessoas. Entretanto, são agrupamentos fechados e identitários.

Há uma nostalgia da comunidade - como escreve Peter Pelbart, ao acompanhar o trabalho de Jean-Luc Nancy. Ele aponta que há um desenrolar da história sob um fundo de uma comunidade perdida que acompanha o Ocidente,

[...] a comunidade perdida ou rompida pode ser exemplificada de várias formas, como a família natural, a cidade ateniense, a república romana, a primeira comunidade cristá, corporaçôes, comunas ou fraternidades [...] Sempre referida a uma era perdida em que a comunidade se tecia em laços estreitos, harmoniosos, e dava de si mesma, seja pelas instituiçóes, ritos símbolos, a representação de sua unidade (PELBART, 2006, p. 31-32).

Para Nancy (1986 apud PELBART, 2006), a comunidade perdida, harmoniosa e unitária, nunca existiu e não passa de um fantasma. Mas como pode ser táo forte a presença desta nostalgia de uma comunidade harmoniosa inexistente, diante da história humana de conflitos? Michael Hardt e Antonio Negri (2005) percebem esta nostalgia, e pensam relacionar-se a uma ameaça frente à fragmentação da sociedade individualista. Assim, são exaltadas as antigas formaçôes sociais, fortalecidas pelos agrupamentos em torno do amor à pátria, ao trabalho e à família, cujo "[...] objetivo final é a reconstrução do corpo social unificado [...]" (HARDT; NEGRI, 2005, p. 250).

Parece haver hoje um saudosismo dessa comunidade que nunca existiu, constituída por laços de semelhança, por meio de algum traço que conecta as pessoas identitariamente. Existe algo próximo entre este pensamento e as tribos táo aceitas pelo corpo social: hippies, punks, etc. Podemos pensar esta concepção de comunidade como unidade identitária bem operante e à serviço do capital e de sua necessidade de segmentarização e identificaçáo dos movimentos do corpo social.

O que embala essas falas saudosistas não é a comunidade como acontecimento, mas sim a ideia de comunidade como unidade, fusão, identidade. Contrariamente, a comunidade como acontecimento tem por condição o oposto do que supostamente se perdeu e, para sua existência, necessita da heterogeneidade e da distância. Contudo, não se trata de postular um modelo de comunidade, mas de questioná-la (NANCY, 1986 apud PELBART, 2006).

\section{Cena 1}

No último ensaio do coral cênico em 2011, um rapaz jovem, que parecia bem alcoolizado, ficou um tempo observando, através do vidro que separa a sala de ensaio da rua, o que dentro acontecia. Quando algum participante do coral olhava para ele, ele apontava para o participante ao lado e, assim, as pessoas cutucavam as outras, acreditando tratar-se de um conhecido de alguém. Foi então que ele decidiu entrar no ensaio no momento em que realizávamos a conversa final, e quando alguns participantes agradeciam ao grupo pelo ano que tivemos. Sentou-se no círculo que já estava formado e ficou a observar. Encerrado o ensaio, alguns participantes já iam embora, ele pode contar 
de sua emoção ao ouvir as falas que foram feitas... Em fevereiro de 2012, no segundo encontro do ano da Oficina de Dança, ele apareceu novamente, bem alcoolizado, mas participou de tudo o que aconteceu. No final, realizamos uma conversa e ele, deitado no chão, dormiu. O segurança da Galeria pediu para que o acordássemos, assim o fizemos, e ele continuou atento ao que acontecia na Oficina. Este jovem apareceu outras vezes nos dias de ensaio de ambas as oficinas, sem necessariamente participar delas, mas olhando o que acontecia por periodos variados de tempo. Então, certo dia, ele foi um dos primeiros a chegar ao ensaio da oficina de dança, e logo entrou na sala perguntando pela coordenadora. Neste dia, a coordenadora náo estava, e ele ficou a esperar pelos demais participantes, novamente dormiu. Quando o ensaio começou, ele acordou e ficou observando o que acontecia, e aos poucos foi tentar aproximaçóes com as pessoas. Uma das funcionárias da Galeria entrou neste momento e questionou a presença deste jovem, por estar embriagado, a um dos participantes. Este respondeu a ela que a postura da oficina havia sido a de tentar acolher o jovem e ir conversando sobre a questão do álcool e das regras da oficina, em vez de pedir aos seguranças que o retirassem. A funcionária pareceu não gostar e ficou um tempo observando o ensaio, $o$ jovem saiu. O jovem jogava-se em cima dos demais sem qualquer medida, nas Oficinas de Dança; e era sempre necessário colocarmos para ele o que dava para fazer e o que não dava, o cuidado que precisávamos ter. Um participante do espaço, que sempre se aproxima das pessoas recém-chegadas e faz questão de inclui-las como participantes dançantes, ficou muito próximo deste jovem, dançou com ele algumas vezes, fez massageme foi mostrando posiçóes de contato que utilizava para levantar as pessoas, o jovem tentava uma aproximação com os demais, às vezes muito abrupta, e a resposta das pessoas era variada, alguém tentava dançar junto, modificando aquele ritmo para um ritmo possivel de ser compartilhado ou mesmo dizia que não queria dançar junto no momento. Esta colocação de não querer dançar junto é uma possibilidade constante na oficina e que os participantes respeitam, ou seja, as pessoas podem querer dançar sozinhas - sem contato físico - e não serão advertidas ou coagidas a dançar com outros.

$\mathrm{O}$ jovem não permaneceu nos ensaios, mas sua passagem pela oficina foi um acontecimento que demonstra o esforço de abertura das oficinas do Projeto e as dificuldades implicadas nesta tentativa de abertura. Longe de ser dada e fácil, a possibilidade de que qualquer pessoa venha a participar é fruto de manejos da coordenação das oficinas e da experiência dos participantes.

\section{Cena 2}

Ele compareceu ao ensaio do Coral Cênico com sua mochila, dizendo ter sido encaminhado pelo lugar onde faz acompanhamento de saúde. Logo no início, apresentou sua ficha médica, os problemas de saúde que tinha: as dificuldades para respirar, para falar e para enxergar, junto com suas medicaçôes. Veio à procura do Terapeuta Ocupacional com o meu nome de referência, $e$, nas primeiras vezes em que participou, chamava meu nome ou o do regente, diante da dificuldade de realizar a proposta do momento. Quando na roda, chegava sua vez de falar alguma coisa, de fazer algum som ou gesto, começava a passar mal, a respirar com dificuldade e a dizer "CALMA! CALMA! CALMA!", para o regente e para o resto do grupo. No meio do ensaio de uma canção, ele começava a conversar alto com alguma estagiária de terapia ocupacional, pedindo explicaçôes sobre o caminho necessário para ele ir almoçar, ou para comunicar alguma outra coisa, o que causou irritação em alguns participantes. Então uma senhora, das mais antigas no grupo, lhe contou como o grupo havia tido paciência com ele e com as ligaçóes que constantemente recebe no celular, que nunca desliga. Realizamos alguns exercícios que o ajudaram a respirar com mais calma diante das situaçóes em que encontrava desconforto, e, aos poucos, ele foi concentrando-se nos ensaios e ficando mais atento aos acontecimentos grupais. Seu 'CALMA, CALMA' chegou a ser citado pelo regente, em outros momentos, para o grupo, de uma forma que incluia as falas deste novo participante de forma lúdica e em proveito do trabalho do grupo. Sua presença foi se tornando frequente, e ele, agora um participante, chegava aos ensaios agradecendo ao regente pelo trabalho com sua respiração, e a mim e às estagiárias pela ajuda no espaço. "Obrigada, irmã!'”- ele dizia, junto a abraços.

A presença das estagiárias de terapia ocupacional potencializa muito o trabalho no coletivo. As estagiárias chegam semestralmente através da parceria estabelecida entre o Projeto Cidadãos Cantantes e o Laboratório Arte, Corpo e Terapia Ocupacional da Universidade de Sáo Paulo. Este participante morava distante, em uma casa de acolhida e, por conta dos ensaios, tinha algumas complicações com as instituições para conseguir chegar a tempo de alimentar-se. Pela aproximação de uma estagiária, iniciaram-se contatos com as instituiçóes a fim de poder colaborar com sua situação. Além destas ações mais objetivas, envolvendo ligaçóes e acompanhamento até o metrô, ônibus ou outro meio de transporte, até o local de alimentação de uma pessoa, as estagiárias ajudam na organização dos contatos e das saídas da oficina de coral. Elas são sempre bem recebidas e bem quistas pelos participantes, que tendem a se aproximar e a relatar suas histórias de vida. Fazem-se vínculos bem 
importantes, que sustentam a presença de pessoas em sofrimento psíquico. Foi o que aconteceu com uma participante que permaneceu afastada do grupo por algum tempo por estar ouvindo muitas vozes. A partir da sustentação oferecida por uma estagiária, de quem ficou muito próxima, ela conseguiu comparecer em alguns ensaios e, até em apresentaçóes fora da cidade; outros participantes e os coordenadores também se aproximavam, mas há uma diferença na relação com as estagiárias, que permanecem durante um semestre no grupo. Alguns participantes conseguem expor para as estagiárias as dificuldades que passam no momento com mais abertura do que para o resto do grupo. A partir desta aproximação, uma participante, que chegou a não conseguir sair de casa por conta de seus medos e das vozes que ouvia, começou a ser acompanhada, no transporte coletivo para o ensaio e no retorno para sua casa, por uma outra participante do coral.

Sáo açóes que visam a garantir a permanência de quem queira ficar e pensar a construção deste espaço para qualquer um. Pensamos que o "qualquer" desejado pelo projeto se aproxima do "qualquer" pensado por Giorgio Agamben, "[...] o ser qualquer que seja como for, não é indiferente [...]" (AGAMBEN, 1993, p. 11). O ser que é tomado independentemente do que o identifica a uma classe, ou a outro conjunto já determinado, pois não é por uma característica como ser loiro, baixo, calmo, que ele importa. Ele importa porque sua existência é potência. Não por uma obrigatoriedade de ser algo, de fazer de si uma grande obra; a relação com o qualquer não é a de esperar que o ser seja sua potência na excelência do cumprimento de tarefas, mas que seja sua potência ao afirmar sua existência pelas possibilidades de ação ou de inação, sem carregar com isso falhas e culpabilizaçóes.

Fazer e não fazer como parte da potência de existir, que deve ser assumida e apropriada, como uma ética de vida. Cada pessoa que chega ao Projeto é importante em si e, no trabalho de composição grupal, os modos de presença vão sendo provocados, náo em uma perspectiva de normalizar como cada um deve portar-se, mas de preservar algum andamento de trabalho nas linguagens. Agamben (1993, p. 39) propóe uma ética relacionada à singularidade qualquer, que ressoa com o esforço destes espaços. Ele escreve:

Por isso na ética não há lugar para o arrependimento, por isso a única experiência ética (que, como tal, não pode ser nem uma tarefa nem uma decisão subjetiva) é ser a (sua própria) possibilidade; e expor em cada forma a própria amorfia e em cada ato a própria inatualidade. $\mathrm{O}$ único mal consiste, pelo contrário, em decidir permanecer em débito de existir, apropriar-se da potência de não ser como uma substância ou um fundamento exterior à existência; ou (e é o destino da moral) consiste em considerar a própria potência, que é o modo mais próprio de existência do homem, como uma culpa que é sempre necessário reprimir.

Qualquer é a singularidade que declina a identidade e é determinada principalmente pela totalidade de suas possibilidades. $\mathrm{O}$ qualquer tem uma relação de pertencimento por um ponto de contato que guarda vazios. Ele é uma exterioridade, uma exposição pura. Como diz Agamben (1993, p. 54), “[...] o exterior não é um outro espaço situado para além de um espaço determinado, mas é passagem.”

Toda voz conta, costuma dizer o regente do Coral Cênico. Assim como contam as presenças, os gestos, os olhares, as ideias, as memórias que cada um traz, as sugestóes de músicas, os jeitos de cantar..

Todo corpo conta - compóem e decompóem - no território formado nos espaços das oficinas. Cada ser qualquer traz nas passagens que vive movimentos aos espaços, configurando a possibilidade de serem espaços comuns. Este ponto de contato, sutil, preservado das capturas que impossibilitariam estes encontros. Capturas das vidas das pessoas em sua suposta totalidade, pois mesmo o acompanhamento feito pelas estagiárias, pelos coordenadores e/ou participantes, de buscar o outro que desaparece ou que fica impossibilitado de vir, não tem como objetivo um domínio de sua vida. Desejar este qualquer é desejar conhecê-lo, pois, como escreve Inforsato (2010, p. 50),

[...] o conhecimento deste outrem singular qualquer torna-se mais instigante na medida em que são seus movimentos, seus modos de agir e de fazer gestos no mundo, que agregam e desagregam conjuntos, o que passa a motivar a curiosidade por conhecê-lo.

Não é fácil manter estes espaços abertos.

Cena 3

Um participante chegou ao ensaio acompanhado de uma estagiária de um centro de saúde. Ela apostou no espaço do coral cênico a partir do gosto do participante por música. Quando presente, permanece cantando sozinho alguma canção que lembrou por conta do que alguém falou, ou quase dorme sentado na cadeira. As vezes, participa do aquecimento realizado antes do ensaio das músicas e outras vezes já chega muito cansado. Poder-se-ia achar que ele se desconecta quando parece quase dormir sentado, mas de repente ele inicia uma 
canção relacionada ao que acontece na oficina. Certa vez, estávamos numa experimentação em que tínhamos que, em pequenos círculos, dizer em tons diferentes palavras/desejos aos participantes que permaneciam no meio destes círculos. Foi-se formando um clima em que a sala foi tomada por sussurros e algumas palavras mais compreensiveis. Ele, no entanto, levantando de sua cadeira iniciou um samba na potência de sua voz. Alguns queriam que ele parasse, mas o regente embalou rapidamente na musicalidade que ele propunha $e$ que parecia ser também uma canção. Trazia, assim um pouco do movimento deste participante para a produçâo coletiva.

Há uma experimentação constante no modo como cada um lida com o que o outro traz e com a maneira de trazê-lo. Uma experimentação que instaura movimentos nos espaços de buscar sustentar uma multiplicidade de modos de ser. Quer-se o ser assim, o ser qualquer. Diz-se sim ao ser. Nas palavras de Agamben (1993, p. 84), “[...] assim não significa simplesmente: deste modo ou de outro, com aquelas determinadas propriedades. Assim seja significa: seja o assim. Isto é: sim.”

\subsection{Dois verbetes ou modos de conviver.}

\section{Cena 4}

Num dia de ensaio da Oficina do Coral, bem no início, uma das participantes sentiu-se maltratada por outra. Ela ficou muito chateada e, em certo momento, levou seu incômodo ao grupo, no meio do ensaio de uma canção. Um tanto agitada, como quem tentava conter um choro, ela atravessou o que acontecia, e começou a dizer que não havia gostado do que tinha acontecido, e que estava sendo maltratada por uma pessoa há muito tempo, e que ela náo merecia nada daquilo, que não aguentava mais receber tal tratamento, que não havia feito nada para tal. O grupo, sem entender, tentava perguntar a ela o que havia acontecido, do que ela estava falando, no intuito de poder ajudar. De forma atrapalhada, ela dizia o que havia ocorrido e por que estava táo irritada e com quem. Tentamos administrar a tensão, promover um diálogo entre as pessoas, mas ela estava muito nervosa e quase não nos deixava falar. No ensaio seguinte, a pessoa apontada pela participante como sendo quem a maltratara pediu, logo no inicio, para se pronunciar, pois também estava muito chateada. Ela foi colocando que não sabia a que se referia a fala da outra participante, pois não tinha nada contra ela e etc. A participante, ouvindo esta pessoa, começou a chorar, e recusou-se a falar. Em certo momento, ela foi para um canto da sala seguida por uma das estagiárias, que, pelo vínculo formado, tentava conversar com ela. Porque náo queria falar, ela escreveu num pedaço de papel, para o grupo, que náo estava bem, e que preferia se distanciar por um momento. O primeiro impulso das pessoas da Oficina foi o de dizer para a participante que ela não precisava se distanciar, e que iriamos resolver as coisas, mas ela contava de outras questóes da vida que saltavam no momento, e que ela se sentia muito desestabilizada e, assim, necessitava recolher-se por um tempo. No entanto, as falas dos participantes seguiram para outro caminho, apontando à participante sua importância no trabalho musical, e a importância de suas composiçóes para o grupo, enfim, apontando como seu trabalho faria falta ao grupo por mais que compreendêssemos que ela passava por um momento difícil. Ela ouviu, mas quis afastar-se. Náo compareceu ao ensaio posterior, mas foi, mesmo que atrasada, à apresentação que fizemos. A participante chegou bem em cima do começo da apresentaçâo, um tanto acelerada, sem poder ter compartilhado do aquecimento e do reconhecimento do local. Durante a apresentaçáo, esteve junto, mas em descompasso com os demais; cantava de forma mais acelerada, fora do ritmo do grupo e, em meio a uma canção, começou a comentar com quem estava ao lado sobre os movimentos que os participantes da dança faziam. Coloquei minha mão em suas costas e tentei cantar olhando para ela, na tentativa de que cantássemos juntas e que ela conseguisse entrar mais no ritmo grupal. Ela ficou muito emocionada ao final da apresentação, agradecendo a todos, com os olhos cheios d'água. No semestre seguinte, seguiu comparecendo aos ensaios com regularidade, mais concentrada e compartilhando mais com as pessoas as mudanças em sua vida.

Quando intencionamos náo capturar as vidas que compóem os espaços do Projeto, pensa-se em um modo de se relacionar com a presença e a ausência das pessoas. Com o seu trânsito pelos espaços. Por mais complicado que seja náo ter um número certo de participantes para os ensaios e para as apresentaçóes, há uma necessidade de permitir uma movimentação que não sufoque as relaçóes estabelecidas no espaço. Como supraescrito, quando a participante anunciou que se distanciaria da Oficina, o primeiro impulso do coletivo foi de tentar fazê-la ficar, permanecer constante nos ensaios. Medo de que ela fosse embora e não mais voltasse? Por mais que este fosse o medo, ou caso fosse este um dos afetos presentes no momento, ele não podia ser o primordial e o decisivo. Há uma outra aposta, ou intuição, que permeia a presença dos participantes quanto à sua vinculação com o espaço, uma força maior.

A recusa em participar, em estar presente, pela necessidade de afastamento para que se mantenha 
certa distância, deve "[...] ser tomada afirmativamente, como uma oportunidade de fazer surgir algo inesperado, de irromper uma comunidade subtraída às imagens e aos gestos prontos [...]", como afirma Inforsato (2010, p. 74).

Um outro ser qualquer identifica-se para os demais como cantor solo. Vive uma relação importante com o espaço do coral cênico: em algumas épocas, consegue permanecer nos ensaios e compor com o trabalho grupal, aceitando as propostas e decisóes em comum com os demais; em outras épocas, ele vai aos ensaios e fica rondando o grupo, topa permanecer com os demais durante o aquecimento ou uma música, já chegou a ir aos ensaios e ficar distante, olhando o grupo, olhando vitrine afora, ouvindo as músicas de seu celular. Num ano em que trabalhávamos os sete elementos, ele levou uma música que foi escolbida pelo grupo para compor o repertório e, junto à outra participante, dedicou-se muito aos ensaios. Era no momento das apresentaçóes que ele se destacava mais, com muita energia; aqueles pareciam ser momentos muito importantes para ele. Nas ocasiōes em que leva uma música e não a fazemos exatamente do jeito que quer, ele se irrita muito; são músicas que ele parece querer cantar só, no espaço. Algumas vezes diz que se distanciou do grupo, por ter sido expulso; outras, diz que o coral está atrapalhando sua carreira solo. Mas ele permanece junto, ou próximo.

Preservar as distâncias é um exercício cotidiano. Nem muito nem pouco, mas o quanto for preciso. Para Gagnebin (2010, p. 253),

[...] poderíamos talvez afirmar que o maior perigo da vida em comum na modernidade e na contemporaneidade jaz, curiosamente, muito mais numa destruição da intimidade por excesso de proximidades invasoras do que num isolamento espacial e social por excesso de distâncias.

A autora afirma que, paradoxalmente, o excesso de proximidade que vivemos, especialmente em grandes cidades, reforça os sentimentos de solidão que tornam as pessoas estranhas umas às outras. Segundo esse pensamento, a proximidade excessiva entre as pessoas acaba sendo uma constante ameaça de invasão, que acarreta a criação de uma distância interior como a indiferença e a frieza.

A reciprocidade do olhar é citada por ela como um exemplo desse excesso. Os habitantes das cidades são bombardeados por informaçôes visuais e experimentam um empobrecimento da possibilidade de estabelecer comunicação através das trocas de olhares. Por exemplo, náo é comum uma pessoa permitir que outra a olhe no transporte público sem com isso ficar incomodada, irritada ou mesmo confrontar quem a olha. O seu olhar no meu talvez só seja preservado, atualmente, nas relaçóes amorosas, afirma a autora. No entanto, as oficinas de Coral Cênico e de Dança e Expressão Corporal são interessantes laboratórios deste contato, tendo a primeira, inclusive, elaborado um repertório sobre o olhar.

Gilles Deleuze (2008), em uma entrevista a Antoine Dulaure e Claire Parnet, fala do casal maldito como aquele no qual o silêncio não cabe; assim, quando a mulher se distrai e se cala, o homem já pergunta o que ela tem e pede para que ela fale, expresse, comunique. Segundo o autor, somos bombardeados de palavras e imagens inúteis, o que faz com que o problema se desloque da necessidade da expressão para o silêncio e o direito ao silêncio. Ele diz que "[...] o problema não é mais fazer com que as pessoas se exprimam, mas arranjar-lhes vacúolos de solidão e de silêncio a partir dos quais elas teriam, enfim, algo a dizer [...]" (DELEUZE, 2008, p. 161-162).

Operar por um pathos da distância, como escreve Roland Barthes (2003a, b), para manter a potência do espaço. A distância, para Barthes, é um ponto fundamental para possibilitar o viver junto, de modo que ela possa preservar uma solidão que não seja um isolamento, e um coletivo que náo seja uma fusão das partes que o compóem. Distância não é afastamento, nem separação negociada. A distância é um espaçamento que preserva a diferenciação entre os seres, seus contrastes, atritos, ou seja, um espaço entre que permite que se mantenham singulares.

Não ter a pretensão de tomar conta da vida das pessoas, de interferir em seus cotidianos, em outros ambientes por quais circulam, mas aproximar-se e intervir no que interfere em suas participaçóes, poderia ser um modo de operar pela distância. Não é somente aceitar que a participante, supracitada mais anteriormente, permaneça afastada de alguns ensaios, mas aceitar seu gesto pelo que traz de singular e de importante ao seu momento de vida.

A aposta maior, mencionada anteriormente - maior no sentido de sua força, mais potente que o medo das rupturas -, é que há um princípio que possibilita esse agrupamento - ou poderíamos chamá-lo comunidade? Um princípio que Barthes denominou delicadeza. O princípio da delicadeza beira uma errância social e um estado amoroso. A delicadeza é o que nos agrega desprovidos de obrigatoriedade e por distância e cuidado. Como explica Barthes (2003a, p. 260), "[...] ausência de peso na relação, e, entretanto, calor intenso dessa relação. O princípio seria: lidar com o outro, os outros, não manipulá-los, renunciar ativamente às imagens (de uns, de outros), 
evitar tudo o que pode alimentar o imaginário da relação." Distância e delicadeza, aliados a um modo de operar juntos, poderiam ser qualidades para a formação de uma comunidade por vir?

Dia de ensaio no Coral Cênico, e dia de despedida das estagiárias. O regente avisou, na semana anterior, que chegaria bem atrasado. As estagiárias levaram as letras das canções para ensaiarmos, e eu levei o som. Durante o aquecimento, propusemos que andássemos pelo espaço, ao som do CD, de modos esquisitos, e, em seguida, fizemos um jogo dos sons para "concentração" do grupo. Seguimos para o trabalho com as cançöes ao irmos passando algumas letras das músicas. Aquela participante que pediu para se afastar compareceu e se emocionou bastante ao cantar uma letra de sua composição, que a lembrava de seu irmão. Como de costume, para a despedida das estagiárias, uma representante do PACTO comparece para realizar uma conversa de finalização. Na chegada da docente, um participante logo começou a falar, bem emocionado, como sempre fica. Ele disse que as estagiárias o ajudaram e acolheram no grupo, que o chamaram para o grupo enquanto os demais o chicoteavam. Disse ainda que, ao ser chicoteado pelas pessoas, era expulso do grupo. Uma outra participante, quase a mais velha do grupo, disse a ele que ela náo concordava com sua fala e que ela sempre dera apoio para que ele não cantasse uma certa canção, que na época causava desconforto para ele. Outro qualquer disse ser ruim quando as estagiárias vão embora, colocação que gera concordância, ao menos pelo balançar afirmativo das cabeças dos demais e por falas que se emendam a esta, confirmando este sentimento. A docente assinala um ponto positivo em se ter um grupo de pessoas passageiras (como é o caso das estagiárias) e um grupo de pessoas constantes, pois as passageiras podem dar uma nova energia para, por exemplo, se vivenciar problemas do Projeto. A participante - quase a mais velha - concordou, e disse ficar muito feliz ao ver as pessoas novas participarem do grupo. A conversa segue e, em determinado momento, uma pessoa diz achar interessante esses papéis que vão sendo rodiziados neste espaço: as estagiárias que se tornam coralistas, quando resolvem voltar ao espaço mesmo com o final do estágio; os participantes que levam o ensaio, mesmo com a ausência do regente; os participantes que se colocam para tomar parte nas negociaçóes com a galeria ou junto com a coordenação, em relação aos convites recebidos pelo grupo para apresentaçóes, e por ai vai... - como naquela manhã em que todos tinham sido regentes. Mais para of final da conversa, os dois participantes com mais idade olham-se e um pergunta para o outro: "Você não se sente mais jovem de vir a esses ensaios?."

A fala da participante sobre a variaçáo dos papéis é bem interessante para pensar a forma de funcionamento das oficinas. Além de serem pesquisas e criaçôes coletivas, tanto na Oficina do Coral Cênico, a partir das músicas, como na Oficina de Dança e Expressão Corporal, a partir do trabalho com o corpo, os diversos participantes vão assumindo funções diferentes conforme seja necessário nas situaçóes, numa forma de trabalho cooperativa.

Maurizio Lazzarato escreve sobre a potência de cooperação entre cérebros como uma forma de cocriação e invenção. Esta cooperação acontece a partir do momento em que as pessoas têm acesso aos bens coletivos, como a ciência, o saber e a saúde..., que, por sua vez, dependem da difusão de dispositivos tecnológicos, das redes comunicacionais e educacionais. A cooperação entre os cérebros “[...] não necessita, para existir, da empresa e do capitalismo [...]" (LAZZARATO, 2006, p. 120). Ela não é uma atividade especializada. $\mathrm{O}$ autor cita, como exemplo, a dinâmica de cooperação entre cérebros posta em prática por indígenas de Chiapas, no México, frente à colonização de suas formas de vida. Escreve que esses indígenas construíram uma esfera de perguntas e respostas que tiveram a intervençâo de muitos sujeitos, que levaram, cada qual, sua capacidade de invenção, em um movimento capaz de colocar em jogo saberes hegemônicos.

A cooperação entre cérebros seria como cada um agrega a uma memória social sua própria potência inventiva. Ela é uma abertura de espaço-tempo para a invençáo, que foge das vontades unilaterais de apropriação. Cada participante dos Cidadãos Cantantes, como seres quaisquer, exerce sua presença, ao trazer sua potência de criar para compor com o que é produzido. Ser um pouco do que se precisa ser, como se é, no sentido de poder circular entre as funçôes do grupo: alguém que acolhe as chegadas dos novos participantes; alguém que liga e acompanha o colega que necessita; alguém que ajuda na coordenação do trabalho cênico e musical; alguém que propóe um tema a ser trabalhado; alguém que leva uma música para ser cantada pelo Coral Cênico ou para ser dançada na Oficina de Dança; alguém que leva uma câmera fotográfica ou filmadora para registrar o que ali acontece...

\section{Conclusão}

A cooperação constitui a forma de existência desta comunidade de quaisquer. A forma que organiza e preserva a duração das Oficinas do Projeto, com suas capacidades de construir novos problemas para o campo social e colocar à prova suas respostas. "Na cooperação entre cérebros (ou subjetividades 
quaisquer), é menos a natureza 'imaterial' do que a forma ético-política da atividade e suas modalidades de organização que nos interessam [...]" (LAZZARATO, 2006, p. 127).

Contudo, esta potência de cooperação no trabalho entre as pessoas é também utilizada pelas empresas e pelo sistema capitalista, que se apropriam daquilo que é produzido pelos pequenos cérebros, ao tornar a invenção uma propriedade intelectual. Quando uma invenção é tomada como propriedade intelectual de uma empresa, coloca-se uma posiçáo política que determina quem cria e quem reproduz a criação. É uma captura da produção social que não reconhece a natureza cooperativa e o acontecimento da invenção.

Os participantes, junto à coordenação da Oficina de Dança e Expressão Corporal, têm apresentado seus trabalhos como sendo realizados com direção e criaçáo coletiva do grupo, como uma forma de afirmar e preservar este caráter cooperativo e coletivo da criação. As decisóes são tomadas por todos e não buscam minimizar o dissenso. No entanto, há um sentimento de empatia entre os participantes, talvez pelas intensidades que compartilham juntos, que consegue resistir aos conflitos que emergem nas discussões coletivas sobre os compromissos e o funcionamento da oficina. Como escreve Lazzarato (2006, p. 132-133),

[...] estar em cooperação deve ser um sentir junto, um "se afetar" junto. A amizade, o sentimento de fraternidade, de compaixáo (pietàs), são a manifestação da relação de empatia que é necessário pressupor para explicar a constituição e a dinâmica da cooperação entre cérebros.

Seguem essas oficinas, agrupamentos que nada garantiram aos seus participantes, exceto a possibilidade da criação conjunta e da intensidade das experiências. Aproximam-se, assim, da potência de serem comunidades pautadas na delicadeza de estar junto. Comunidades que não são medidas pelas condições de pertencimento e nem pela ausência de tais condiçóes, e que só existem pelos efeitos que causam em seus participantes e pelos encontros que aumentam a potência de agir, promovendo assim, relaçóes, criaçóes e saúde. Comunidade na qual "[...] os homens podem não ser suas biografias e serem somente seus rostos." Não rostos como símbolos de identidades ou representaçóes sociais, mas como exterioridades singulares. Comunidade sem pressupostos e sem sujeitos (AGAMBEN, 1993, p. 52).

\section{Referências}

AGAMBEN, G. A comunidade que vem. Lisboa: Presença, 1993.

BARTHES, R. Como viver junto: simulaçóes romanescas de alguns espaços cotidianos, cursos e seminários no College de France (1976-1977). São Paulo: Martins Fontes, 2003a.

BARTHES, R. O neutro. Anotaçóes de aulas e seminários ministrados no Collège de France, 1977-1978/Roland Barthes. São Paulo: Martins Fontes, 2003b.

DELEUZE, G. Espinosa: filosofia prática. São Paulo: Ecuta, 2002.

DELEUZE, G. Conversaçōes. São Paulo: Editora 34, 2008.

GAGNEBIN, J. M. Walter Benjamin ou a história aberta. In: BENJAMIN, W. Obras escolhidas: magia e técnica, arte e política. São Paulo: Brasiliense, 2010. p. 7-19.

HARDT, M.; NEGRI, A. Multidão: guerra e democracia na era do império. Rio de Janeiro: Record, 2005.

INFORSATO, E. A. Desdobramento: constelaçôes clínicas e políticas do comum. 2010. 217 f. Tese (Doutorado em Educação) - Universidade de São Paulo, São Paulo, 2010.

LAZZARATO, M. As revoluçôes do capitalismo. Rio de Janeiro: Civilização Brasileira, 2006.

PELBART, P. P. Vida capital: ensaios de biopolítica. São Paulo: Iluminúras, 2006.

\section{Contribuição dos Autores}

Juliana Araújo Silva realizou a pesquisa de mestrado sob orientação de Elizabeth Lima. As duas autoras contribuíram igualmente para a redação do texto. 